\title{
REVIEW
}

\section{Hedgehog signalling in endocrine development and disease}

\author{
Peter J King, Leonardo Guasti and Ed Laufer ${ }^{1}$ \\ Barts and the London School of Medicine, Centre for Endocrinology, London EC1M 6BQ, UK \\ ${ }^{1}$ Department of Pathology and Cell Biology, Columbia University Medical Center, New York, New York 10032, USA \\ (Correspondence should be addressed to P J King; Email: p.j.king@qmul.ac.uk)
}

\begin{abstract}
The hedgehog (Hh) pathway is an evolutionarily conserved signalling pathway that is required for many essential tissue and cellular properties such as patterning fields of cells or regulating cell differentiation and proliferation. Disruption of the pathway results in serious pathologies. In this review, we
\end{abstract}

provide an update on recent findings in the field of vertebrate Hh signalling and also describe contributions of Hh signalling to the development, maintenance and pathology of endocrine tissues.

Journal of Endocrinology (2008) 198, 439-450

\section{Hedgehog signalling}

The hedgehog $(H h)$ gene was originally identified in the seminal work of Nusslein-Volhard \& Wieschaus (1980) in which they performed mutagenesis screens of Drosophila and isolated and characterised mutants defective in embryonic cuticle formation. One of these they named $H h$ because mutation of the gene resulted in the disorganised denticles forming a spiky pattern. Subsequent investigations demonstrated that $H h$ encodes an intercellular signal with multiple critical functions as a regulator of embryonic development. Hh homologues have since been identified in many invertebrates and vertebrates, and found to play similar vital roles controlling tissue patterning, and cellular differentiation and proliferation both during embryonic development and in the control of stem cell behaviour and homeostasis in the adult.

\section{Ligands}

The three mammalian homologues of Drosophila Hh are Sonic $H h(S h h)$, Indian Hh (Ihh) and Desert Hh (Dhh). Each of the Hh proteins is processed post-translationally, and the precursor forms undergo multiple covalent modifications to produce mature signalling molecules. Hh proteins undergo autocatalytic cleavage that removes the carboxyl-terminal domain (Lee $e t$ al. 1994, Bumcrot et al. 1995) and simultaneously modifies the newly exposed carboxyl-termini of the amino-terminal signalling molecules by the addition of cholesterol (Porter et al. 1996). These proteins are further modified into their mature forms by signal peptide cleavage and palmitoylation at amino-terminal cysteine residues (Pepinsky et al. 1998) by the acyltransferase Skinny Hh (Chamoun et al. 2001). This dual lipidation makes Hh proteins highly hydrophobic, and the release of processed $\mathrm{Hh}$ from the plasma membrane is thus an active process. Secretion is mediated by 12 pass transmembrane protein Dispatched (Disp), which is required for signalling to non-adjacent cells (Burke et al. 1999). The majority of secreted $\mathrm{Hh}$ found in soluble multimeric forms thought to assume micelle-like structures (Chen et al. 2004, Goetz et al. 2006). Hhs are the only known proteins that are covalently linked to cholesterol in this way. The requirement for cholesterol modification partially underlies the spectrum of developmental disorders observed in Smith-Lemli-Opitz syndrome (SLOS, OMIM 270400), a condition in which defects in 7-dehydrocholesterol reductase (DH7CR), an enzyme required for the formation of cholesterol from 7-dehydrocholestrol, leads to abnormalities that overlap those seen in cases of impaired $\mathrm{Hh}$ signalling (Kelley \& Hennekam 2000).

\section{Signal transduction pathway}

Hh proteins bind 12 pass transmembrane receptors Patched1 (Ptch1) and Ptch2 on responding cells (Fig. 1). Binding to these receptors promotes Ptch internalisation and derepresses the activity of Smoothened (Smo), a seven pass transmembrane protein of the $G$ protein-coupled receptor family that is related to the frizzled class of Wnt receptors. Following Hh binding to Ptch, Smo is phosphorylated on its intracellular carboxylterminal tail (Chen et al. 2004) and undergoes a reciprocal translocation from intracellular vesicles to the plasma membrane (for a review, see Huangfu \& Anderson 2006). 


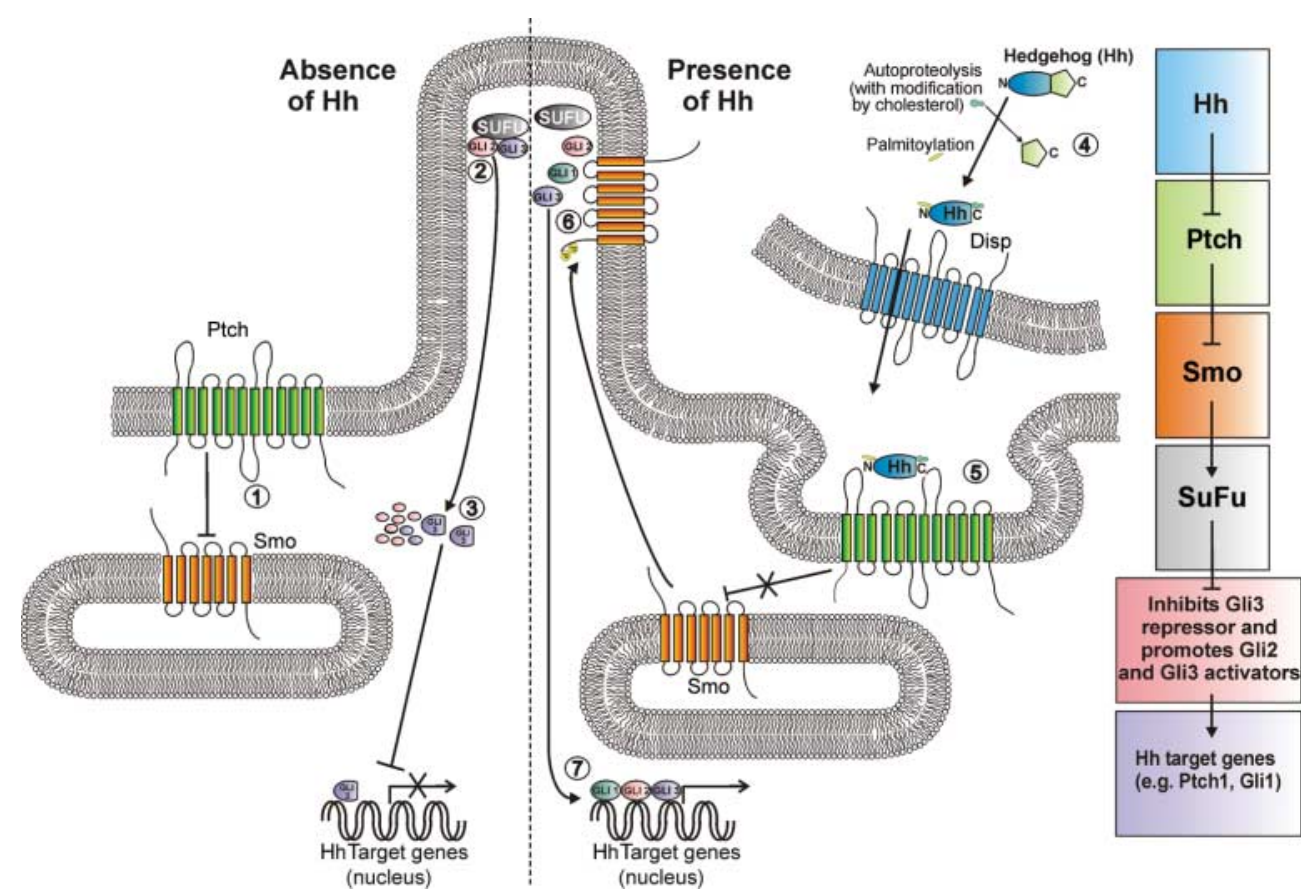

Figure $1 \mathrm{~A}$ scheme for Hh signalling. In the absence of Hh ligand, Ptch, located at the base of the cilium, inhibits Smo, possibly via a small molecule (1). Gli2 and 3, along with SuFu, are located at the tip of the cilium (2). IFT is required for movement of these molecules in and out of the cilium and they are proteasomally processed outside the organelle (3). Processing cleaves Gli3 (and Gli2) to produce a transcriptional repressor that inhibits the expression of $\mathrm{Hh}$ target genes and degrades Gli2. Hh is synthesised in signal-producing cells as a precursor molecule that is cleaved to remove the $\mathrm{C}$ terminus and is simultaneously modified by cholesterol addition. Following palmitoylation at the $\mathrm{N}$ terminus, it is secreted via Disp (4). Hh binding to Ptch on target cells promotes internalisation and relieves the repression Ptch exerts on Smo (5). Smo then translocates from endosomes to the tip of the cilium (6) resulting in the inhibition of processing of the Glis which are then able to activate transcription of target genes, including Gli1 (7). A simplified pathway is shown on the right-hand side of the panel. For details see text.

The inhibition of Smo by Ptch is sub-stoichiometric, and the two proteins do not appear to physically interact, which raises the still unanswered question of how Ptch inhibits Smo activity. Both Ptch and Disp have homology to bacterial small molecule pumps and the Niemann-Pick C1 cholesterol transporter (Carstea et al. 1997, Loftus et al. 1997), which has led to the suggestion that, in an $\mathrm{Hh}$ binding-modulated fashion, Ptch might transport small molecule regulators of Smo activity. Adding support to this idea, the sterol-related alkaloid cyclopamine and the purine homologue purmorphamine can bind Smo and inhibit or activate it respectively. One candidate for an endogenous negative regulator of Smo is 7-dehydrocholesterol ((pro-) vitamin D3), which can be transported out of the cell by Ptch1, and accumulates in the plasma of SLOS patients (Bijlsma et al. 2006). Interestingly, oxysterols, which are cholesterol oxidation products, can activate the Hh signalling pathway by binding to Smo, raising the additional possibility that oxysterols or related molecules are natural intracellular Smo agonists (Corcoran \& Scott 2006, Dwyer et al. 2007). These data, together with the modification of $\mathrm{Hh}$ and the presence of sterol-sensing domains in Ptch and Disp
(Kuwabara \& Labouesse 2002), underscore the importance of cholesterol synthesis both in cells that produce $\mathrm{Hh}$ and those which receive $\mathrm{Hh}$ signals.

Ptch and Smo act through a signal transduction cascade that culminates in the modulation of the activity of the Gli family of zinc finger transcription factors. There are three Gli genes in mammalian cells, Gli1, Gli2 and Gli3, which have partially overlapping functions. In the absence of Hh signalling, Gli2 and Gli3, but not Gli1, are expressed at significant levels. In uninduced cells, these factors are phosphorylated by protein kinase A (PKA), casein kinase 1 (CK1) and glycogen synthase kinase $3 \beta$ (GSK3 $\beta$ ) (Sheng et al. 2006, Tempe et al. 2006 , Wang \& Li 2006) and ubiquitinated via interaction with the E3 ligase $\beta$ transducin repeat containing protein $(\beta \operatorname{TrCP})$ (Wang \& Li 2006). These modifications lead to proteasomal processing that degrades the majority of Gli2, while limited proteolysis of Gli3 and Gli2 removes a carboxylterminal activation domain, producing truncated repressor forms that inhibit the expression of Hh target genes.

Activation of Smo via Hh-mediated inhibition of Ptch activity inhibits proteolytic processing of Gli2 and Gli3, and leads to the production of full-length transcriptional activator 
forms of these proteins. This changes the ratio of activator and repressor Gli isoforms in the nucleus, and thus alters the expression of $\mathrm{Hh}$ target genes by a combination of transcriptional derepression and activation. Gli1 transcription is induced as a primary response to Hh signalling, and Gli1 acts solely as a transcriptional activator to prolong or increase Hh target gene expression. Gli1 thus acts in conjunction with Gli2 and Gli3, although the loss of Gli1 alone does not cause Hh signalling defects (Bai et al. 2002). Gli3 mRNA expression is also regulated by $\mathrm{Hh}$ signalling, although in a negative fashion (Marigo et al. 1996). Thus, pathway activation leads not only to the induction of positively acting transcription factors, but also to the inhibition of negatively acting ones.

Among the Hh targets are several components of the $\mathrm{Hh}$ signalling system, including Ptch1 and Hh interacting protein (Hip). Hip is a transmembrane glycoprotein that binds all forms of Hh with similar affinity to Ptch1 and acts to sequester $\mathrm{Hh}$ and inhibit signalling in a negative feedback loop (Chuang \& McMahon 1999, Bak et al. 2001). The expression of these genes, in particular Gli1, which is not observed in the absence of $\mathrm{Hh}$, is therefore a useful marker of cells actively transducing an Hh signal (Ahn \& Joyner 2004, Vokes et al. 2007).

\section{Signalling and cilia}

Recent work has highlighted the importance of primary cilia, which had previously been thought to be functionless vestigial organelles, for Hh signalling (for a recent review, see Eggenschwiler \& Anderson 2007). Primary cilia are nonmotile and are found on the surface of most, if not all, vertebrate cells as solitary microtubular protrusions extending from the centriole or basal body. Defects in intraflagellar transport (IFT), which is required for the formation and function of primary cilia, present with a spectrum of defects that overlaps those seen in Hh signalling mutants (see below). Examples of ciliopathies with $\mathrm{Hh}$ mutant markers include Bardet-Biedl syndrome (BBS, OMIM 209900) and MeckelGruber syndrome (OMIM 249000), which are complex disorders involving multiple developmental defects including polydactyly, situs inversus and hallmarks of holoprosencephaly (for reviews see, Davis et al. 2006, Tobin \& Beales 2007).

A rationale for these observations was provided in a series of studies that revealed that IFT proteins and other ciliary components are required for Hh signalling. In the absence of IFT, there is no Gli activator or repressor activity with the result that there is no response to ligand (Huangfu et al. 2003, Haycraft et al. 2005, Huangfu \& Anderson 2005, Liu et al. 2005, May et al. 2005). IFT mutations do not completely phenocopy mutations that inactivate the Hh pathway because the contribution of repression and activation of gene expression varies between cell types and both processes are affected in most ciliopathies. IFT is required for the transport of Gli1, Gli2 and Gli3, along with Suppressor of Fused $(\mathrm{SuFu})$, into the cilium where they localise at the tip (Haycraft et al. 2005) and are modified in a poorly understood manner by a complex that includes SuFu (Kogerman et al. 1999,
Svard et al. 2006). Fused (Fu) is crucial for Hh signalling in Drosophila but in mammalian cells the importance of its role is as yet unclear (Chen et al. 2005, Merchant et al. 2005). In the absence of ligand, Gli2 and Gli3 are processed by the proteasome at the base of the cilium whereupon they can translocate to the nucleus and repress target gene transcription.

Upon binding $\mathrm{Hh}$, Ptch1 is internalised from its position at the base of the cilium in uninduced cells and Smo becomes localised to the cilium tip (Corbit et al. 2005, May et al. 2005, Rohatgi et al. 2007) where it promotes the formation of activators and inhibits formation of repressors in an as yet unexplained manner. Part of the inhibition of Smo by Ptch is thus mediated by preventing entry of Smo into the cilium. This organelle is utilised apparently as a centre for accumulating pathway components that link Smo to Gli either in order to promote efficient signal transduction, or perhaps to allow for an ordered and vital sequence of protein interactions and modifications (Caspary et al. 2007).

\section{Hh signalling during development, in the adult and in disease}

Hh signalling plays many crucial roles during embryonic development, with the Gli family of transcription factors activating and repressing transcription of target genes in a multitude of settings. These include the notochord and floor plate which are required for neural tube patterning and the zone of polarising activity which is involved in limb development, and in many other developing organs and tissues (for review see Ingham \& McMahon 2001). Hh signalling also has importance beyond development and is required for tissue maintenance and differentiation in the adult, for example in the gastrointestinal tract (Parkin \& Ingham 2008), T-cell activation (Outram et al. 2000), haematopoiesis (Bhardwaj et al. 2001) and skin (Athar et al. 2006), with the control of stem cell behaviour being a common observation (Lai et al. 2003, Machold et al. 2003, Palma et al. 2005, Trowbridge et al. 2006, Zhou et al. 2006, Peacock et al. 2007).

Hh can act as a morphogen, a simple inductive signal, a mitogen, a survival factor or a chemoattractant, with the relevant modality depending on the specific tissue and developmental context. When Hh patterns a tissue as a morphogen, such as during ventral neural tube development, a gradient of ligand is established and cells respond to variations in the local concentration of ligand by differentially regulating target gene expression (Ingham \& McMahon 2001, Ashe \& Briscoe 2006). It is thus perhaps not surprising that many genes are involved in establishing and shaping the $\mathrm{Hh}$ ligand gradient. The Hh lipid modifications lead to interaction with the extracellular matrix and thus restrict diffusion (for review, see Guerrero \& Chiang 2007). Several extracellular Hh-binding proteins such as Gas1, Cdo and Boc facilitate $\mathrm{Hh}$ signalling by increasing sensitivity to low concentrations of ligand, while others, such as Hip, sequester Hh and reduce signalling (Tenzen et al. 2006). Hh signalling 
regulates the expression of many of these Hh-binding factors, including Ptch1 itself, and thus activation of the pathway can lead to subsequent modification in the shape and steepness of the gradient (Martinelli \& Fan 2007a,b). Modulation of the extracellular concentration of $\mathrm{Hh}$ might similarly be important for establishing chemoattractant Hh gradients, such as that which is sensed by the growing axons of dorsal commissural neurons as they extend towards the ventral midline of the neural tube (Charron et al. 2003).

The differential response of cells to variations in the $\mathrm{Hh}$ ligand gradient appears to be exhibited through graded alterations in the activity of the Gli transcription factors. Thus, a low level of $\mathrm{Hh}$ response might be achieved through reduced production of Gli repressor protein, while a higher level might be achieved by producing Gli activator from Gli repressor, or inducing additional activator expression de novo. By modulating both the type of Gli protein produced as well as utilising multiple Gli genes, cells can achieve a wide range of $\mathrm{Hh}$ responses. It is now clear that these responses vary with tissue context. Thus, for example, in the spinal cord, Gli2 appears to be the most significant family member, while in the limb Gli3 is most significant (Ahn \& Joyner 2004, Bai et al. 2004).

Developmental disorders of Hh signalling can be separated into those that result primarily from either inactivation (constitutive repression) or overactivation of the pathway. Holoprosencephaly (HPE) results from inactivation of the pathway, with defects observed in Shh (HPE3, OMIM 142945) (Nanni et al. 1999), Ptch1 (HPE7, OMIM 610828) (Ming et al. 2002) and Gli2 (HPE9, OMIM 610829) (Roessler et al. 2003), as well as DH7CR (SLOS, OMIM 270400). The commonly used Smo binding molecule and $\mathrm{Hh}$ pathway inhibitor cyclopamine, a teratogenic alkaloid derived from the corn lily (Veratrum californicum), was discovered after it was observed that the offspring of ewes that grazed on the lilies during pregnancy were born with holoprosencephaly (Keeler \& Binns 1968). Pallister-Hall syndrome (PHS, OMIM 146510), which encompasses a number of symptoms including polysyndactyly, hypothalamic hamartoma and internal organ malformations (see below), is caused by truncations of the GLI3 gene which mimic the repressor form of the transcription factor resulting in constitutive inhibition of Hh signalling (Bose et al. 2002, Hill et al. 2007).

Inappropriate activation of $\mathrm{Hh}$ signalling contributes to several cancers. Gorlin syndrome (basal cell nevus syndrome, OMIM 109400) is a disorder with predisposition to basal cell carcinoma (BCC), medulloblastoma and rhabdomyosarcoma (Gorlin 1995), as well as skeletal and other abnormalities. Inactivating mutations in PTCH1 are responsible for this syndrome (Hahn et al. 1996, Johnson et al. 1996) and inactivating mutations in PTCH1 (Gailani \& Bale 1997), or activating mutations in SMO (Lam et al. 1999) and other pathway components (Reifenberger et al. 2005) are estimated to be present in up to $76 \%$ of sporadic BCC. Hh pathway mutations have also been described in $25 \%$ of sporadic medulloblastomas (Zurawel et al. 2000). Adult reactivation of the Hh pathway is associated with lung cancer (Watkins et al. 2003), glioma (Dahmane et al. 2001), gastric tumours (Berman et al. 2003) and others discussed below (see Table 1).

\section{Hh signalling in endocrine tissues}

\section{The pancreas}

The developing gut is formed from a primitive endodermal tube that gives rise to the entire digestive system and associated organs from the pharynx to the colon. During development organs such as the pancreas, lungs and liver are derived from endodermal buds that grow out of the walls of the gut tube (for review see, Kiefer 2003). Studies on Hh signalling during gut development have elucidated a general mechanism whereby endodermal $\mathrm{Hh}$ signals act on the surrounding mesenchyme via an epithelial-mesenchymal inductive mechanism. One example of this is seen in pancreatic development, and although space precludes the discussion of similar crosstalk mechanisms that control the lung and liver development, these are well covered in other reviews (Warburton et al. 2000, Shannon \& Hyatt 2004, Watkins \& Peacock 2004).

The pancreas contains two primary tissues, comprising the exocrine and endocrine pancreas. The exocrine pancreas is made up of acinar cells, which constitute the majority of cells in the pancreas, and ductal cells. Acinar cells produce digestive enzymes that drain into the duodenum via the ductal tissue. The islets of Langerhans are clusters of cells found within the exocrine pancreas and constitute the endocrine pancreas. These endocrine islets are themselves composed of five different cell types: $\boldsymbol{\alpha}$-cells (which produce glucagon), $\beta$-cells (insulin), $\delta$-cells (somatostatin), $\varepsilon$-cells (ghrelin) (Prado et al. 2004) and PP-cells (pancreatic polypeptide), and the hormones these cells produce regulate blood glucose levels (for reviews, see Slack 1995, Docherty 2001, Murtaugh 2007).

The pancreas develops from two buds forming on the dorsal and ventral sides of the posterior foregut. These buds come into contact and fuse after stomach rotation (for review, see Murtaugh 2007). The gut and pancreatic development proceeds under the control of pancreatic and duodenal homeobox 1 ( $P d x 1)$, a homeodomain-containing transcription factor essential for the development and function of the gland (Jonsson et al. 1994, Offield et al. 1996). Shh and Ihh are expressed initially throughout the gut including within the presumptive pancreas region during early mouse development (Bitgood \& McMahon 1995, Ramalho-Santos et al. 2000, Spence \& Wells 2007), but both are repressed in this region by activin $\mathrm{B}$ and $\mathrm{Fgf} 2$ signals derived from the adjacent notochord (Hebrok et al. 1998). Ectopic activation of $\mathrm{Hh}$ signalling in the pancreas, achieved by the overexpression of Shh under the control of the $P d x 1$ promoter (Apelqvist et al. 1997) or targeted deletion of Ptch1 or Hip (Kawahira et al. 2003), results in severely disrupted endocrine and exocrine pancreatic development. By contrast, disruption of the Shh or 
Table 1 Hedgehog family members expressed in, or responsible for the development of, the endocrine organs discussed in the text are shown together with the role these factors play in the development and function of the organ and their contribution to endocrine pathologies

\section{Hedgehogs Function}

Organ

Prostate

Adrenal Shh

Shh

Testes

Ovary

Dhh

Dhh Ihh

Pituitary

Shh

Hypothalamus

Bone

Shh

Ihh

Adipocytes

Ihh Dhh

Pancreas
Shh Ihh Dhh trophs
Required for bud formation and subsequent branching morphogenesis during development

Required for normal adrenal development

Required for organogenesis, Leydig cell formation and sex cord formation

Hh pathway activation increases granulosa cell proliferation and inhibition increases progesterone production

Shh signal from oral ectoderm required for development. Shh promotes proliferation and differentiation of gonadotrophs and thyrotrophs. Possible post-natal expression and signalling in cortico-

Patterning ventral neural tissue

Controls chondrocyte proliferation and progression to hypertrophy both directly and via secondary signalling in the growth plate; controls osteogenesis during bone formation

Hh signalling inhibitory to adipogenesis

Repression of Shh and Ihh in the developing gut is required for pancreas formation. Ihh and Dhh are expressed in islets at later stages
Pathology

Shh and pathway component expression predictive of pancreatic cancer and metastasis

Adrenal insufficiency observed in Hh-associated conditions Pallister-Hall syndrome and holoprosencephaly $^{a}$

DHH mutations cause testicular dysgenesis

Overexpression contributes to ovarian tumours?

Agenesis observed in holoprosencephaly ${ }^{\mathrm{a}}$. Loss of Shh expression may contribute to adenoma in the adult

Shh null mice show hypothalamic dysgenesis

Ihh null mice have malformed limbs

Ptch1 mutant mice have decreased white adipose tissue. BBS patients exhibit truncal obesity

Disruption of Hh expression causes annular pancreas-like condition. Activation of $\mathrm{Hh}$ signalling in adults is associated with chronic pancreatitis and cancer

${ }^{a}$ Holoprosencephaly phenotypes are possibly secondary to ventral midline patterning defects independent of specific activity in endocrine tissue. See text for details.

Ihh genes in mice (Ramalho-Santos et al. 2000) or inhibition of Hh signalling in chicks with cyclopamine (Kim \& Melton 1998) leads to extension of the pancreatic anlagen. This latter case is similar to the rare annular pancreas condition in which a ring of pancreatic tissue encircles the duodenum, and can inhibit intestinal transit in severe cases. Taken together these data indicate that the pattern of Shh and Ihh expression in the developing gut creates boundaries between the pancreatic anlagen and those of the stomach and the duodenum, and that continuous $\mathrm{Hh}$ family gene expression within the anlagen is inhibitory to pancreatic development. Indeed, a recent report describing the differentiation of embryonic stem cells into insulin-secreting islet cells for treatment of diabetes used Shh pathway inhibitors to direct the differentiation of endoderm precursors towards a pancreatic lineage (D'Amour et al. 2006).

Ihh and Dhh, along with Ptch1 and Smo, are expressed later in the developing murine pancreas, by 13.5 days post coitum (dpc). While the cell types that express these genes are undefined, expression increases throughout gestation (Hebrok et al. 2000) and persists in the islet cells of the adult organ (Thomas et al. 2000). Studies on islet cells using the rat $\beta$-cell line INS-1 have found that insulin production is controlled by Hh signalling. Cyclopamine treatment inhibits insulin secretion and Shh administration activates the insulin promoter indirectly by increasing $\mathrm{Pdx} 1$ levels (Thomas et al.
2000, 2001). Reduced $P d x 1$ transcription results in adult hyperglycaemia in mice and $P D X 1$ has been identified as a maturity onset of diabetes in the young (OMIM 606391) gene in humans, raising the possibility that impaired $\mathrm{Hh}$ signalling could be a cause of type 2 diabetes in humans.

Chronic pancreatitis (CP) is an inflammatory condition in which, the first exocrine and later endocrine tissue is compromised, with both a reduction in islet cell number and changes in their morphology. In CP, expression of IHH, HIP and PTCH1 is upregulated in the islet cells and is also detectable in the exocrine cells (Kayed et al. 2003). CP is a risk factor for pancreatic cancer, and aberrant $\mathrm{Hh}$ signalling has been observed in the majority of pancreatic tumours (Berman et al. 2003, Thayer et al. 2003). Sonic hedgehog homolog (SHH), which is undetectable in the normal adult gland, is expressed in $70 \%$ of adenocarcinomas (Thayer et al. 2003). In pancreatic tumours, IHH expression is elevated in the islets, as in CP, and displays both a more diffuse pattern of expression than in normal islet cells, and ectopic expression in surrounding tissue, as do PTCH1 and $S M O$. SHH is strongly expressed in pancreatic cancer cells but is not expressed in the islet cells (Kayed et al. 2004). Inhibition of Hh signalling is inhibitory to growth of pancreatic tumours and cells derived from them (Thayer et al. 2003, Feldmann et al. 2007), indicating that Hh signalling might be required for the development of some pancreatic cancers. 


\section{The prostate}

The prostate gland is specified by the prostatic anlagen of the urogenital sinus (UGS) from which it develops in the form of epithelial buds, under the control of androgen produced by foetal Leydig cells. These buds elongate and canalise during branching morphogenesis to form ductal structures that contain the main prostate cell types, neuroendocrine, basal and secretory cells (Cunha et al. 1987). Studies on prostate development in mice have shown that increased expression of Shh in the UGS is observed at the onset of prostate ductal budding and remains elevated during the formation of the main prostatic ducts ( $15 \mathrm{dpc}$ to post-natal day 5$)$. Dhh and Ihh are either undetectable or present at very low levels. Equivalent increases in Shh are not observed in the analogous regions in female mice and it has been determined that $\mathrm{Sh} h$ upregulation in the UGS is dependent upon androgen (Podlasek et al. 1999). Initial experiments in which embryonic UGS tissues were grafted into host animals demonstrated that anti-Shh antibodies block prostate development (Podlasek et al. 1999). However, in organ culture experiments using UGS explants from Shh null mice, prostate buds formed but subsequent branching morphogenesis was disrupted (Freestone et al. 2003, Berman et al. 2004). Further studies have suggested that these contradictory data can be reconciled by functional redundancy with Ihh, which is upregulated in the absence of Shh, maintaining the developmental pathway (Doles et al. 2006). Because combined Shh and Ihh null embryos do not survive to the time of prostate budding, this issue has not been formally resolved. Nonetheless, $\mathrm{Hh}$ signalling is clearly important for prostate development and differentiation. Examination of human prostate cancers has shown upregulation of GLI1 and PTCH1 expression indicating active $\mathrm{Hh}$ signalling, and high $S H H$ levels in prostatic epithelial tissue are correlated with tumours with metastatic potential (Karhadkar et al. 2004, Sanchez et al. 2004). The possibility of targeting the Hh pathway for therapeutic benefit has also been demonstrated, as anti-Shh antibodies and cyclopamine inhibit the growth of both prostate cell lines and tumours (Karhadkar et al. 2004, Sanchez et al. 2004).

\section{The pituitary}

Pituitary organogenesis begins with an invagination of the anterior pituitary placode within the oral ectoderm to form Rathke's pouch. The dorsal region of this structure makes direct contact with a region of the ventral diencephalon, the infundibulum, and this interaction, along with regions within Rathke's pouch and the surrounding mesenchyme, is required for the specification of the pituitary endocrine cell types from progenitor cells within the pouch (for reviews, see Dasen \& Rosenfeld 1999, Scully \& Rosenfeld 2002). These cell types are defined by the particular hormones they produce, which in the anterior pituitary are the corticotrophs (adrenocorticotrophin, ACTH secreting), somatotrophs (growth hormone,
$\mathrm{GH})$, lactotrophs (prolactin), thyrotrophs (thyrotrophin) and gonadotrophs (luteinizing hormone, LH and follicle-stimulating hormone), and in the intermediate lobes the melanotrophs (melanocyte-stimulating hormone, MSH).

Shh is expressed throughout the ventral diencephalon and the oral ectoderm at $8 \mathrm{dpc}$ in the mouse. Its expression is downregulated in the region of the oral ectoderm that gives rise to the invaginating pituitary placode by $9 \mathrm{dpc}$ (Treier et al. 1998, 2001). As in the early stages of pancreas development, Shh expression thus demarcates a molecular boundary that defines the developing pituitary. Ptch 1 is expressed throughout Rathke's pouch indicating that these cells are receiving Hh signals. Shh null mice (Chiang et al. 1996), and mutations in human $\mathrm{SHH}$ or the Hh pathway that cause holoprosencephaly (Odent et al. 1999, Roessler et al. 2003), display pituitary agenesis. While this might reflect an indirect requirement for $S h h$, as $S h h$ null mice have a disrupted ventral diencephalon, which is required for pituitary development (Kimura et al. 1996, Pabst et al. 2000), other experiments indicate $\mathrm{Hh}$ signalling is directly required for the pituitary development. Attenuation of Shh signalling by forced expression of the Hh antagonist Hip under the control of the Pitx 1 enhancer, which is active in the oral ectoderm and Rathke's pouch, results in pituitary agenesis with the formation of only a rudimentary pouch, and normal development of the ventral diencephalon (Treier et al. 2001). Overexpression of Shh in the pituitary under the control of the $\alpha$ glycoprotein ( $\alpha$ GSU) promoter, which is expressed throughout Rathke's pouch, leads to pituitary hyperplasia and premature appearance of $L H \beta$ expression, indicating that Shh promotes proliferation and differentiation of the ventral pituitary cell types (gonadotrophs and thyrotrophs) (Treier et al. 2001). It is unclear as yet whether Shh induces different ventral cell types in a dose-dependent manner. Some evidence suggests that Shh might regulate ventral pituitary cell specification and proliferation at least partially through a secondary bone morphogenetic protein (BMP) 2 signal induced at the Shh expression boundary in the oral ectoderm (Treier et al. 1998).

Studies of the adult human pituitary suggest possible roles for Shh signalling in the mature organ. $\mathrm{SHH}$ is apparently expressed almost exclusively in corticotrophs in normal tissue, which also express PTCH2 and GLI1 (Vila et al. 2005a). However, $\mathrm{SHH}$ is not expressed in corticotrophin-secreting adenomas (Vila et al. 2005b). Treating humans corticotrophinoma- (Vila et al. 2005a), somatotrophinoma- or prolactinoma- (Vila et al. 2005b) derived cell cultures with recombinant Shh led to the increased production of ACTH, GH and prolactin respectively. In rodent pituitary cell cultures, Shh-stimulated ACTH secretion occurs via Glidependent transcriptional activation of pro-opiomelanocortin $(P O M C)$, which is enhanced by co-stimulation with corticotrophin-releasing hormone (CRH). Shh also increased the expression of the CRH receptor $C R H-R 1$, and CRH was shown to stimulate Gli1-dependent transcription (Vila et al. $2005 a$ ). It was also reported that Shh treatment of the mouse 
corticotrophinoma AtT-20 cell line could inhibit its proliferation (Vila et al. 2005b). These data indicate that the loss of $\mathrm{SHH}$ expression in the adult pituitary could play a role in tumour formation and represent a novel avenue of investigation for the treatment of pituitary adenomas.

Shh null mice lack a hypothalamus as well as a pituitary (Chiang et al. 1996). Studies in zebrafish and chicks indicate that Hh signalling promotes the development of the anterior dorsal hypothalamus and inhibits the development of the posterior ventral hypothalamus (Mathieu et al. 2002, Manning et al. 2006). Thus, the importance of Shh for hypothalamic development can further compound the defects in the pituitary and endocrine organs under its control.

\section{The gonads}

The initial phase of gonad development is the formation of the bipotential or indifferent gonads, which occurs in both sexes. The bipotential gonads arise from the mesonephric mesenchyme and coelomic epithelium of the urogenital ridge, and the mesenchyme also produces the Wolffian and Mullerian ductal structures. The primordial germ cells migrate from the base of the allantois along the hindgut and then into the developing gonads, and remain bipotential until $13 \mathrm{dpc}$ in the mouse (for a review, see Wilhelm et al. 2007). Testis development is dependent upon the expression of $\mathrm{Sr} y$ from the $\mathrm{Y}$ chromosome at around $10.5 \mathrm{dpc}$ in the mouse, which triggers all the subsequent steps of testis formation including Sertoli cell differentiation. Sertoli cell precursors express Dhh from $11.5 \mathrm{dpc}$ in the mouse testis and Dhh null male mice exhibit defects in spermatogenesis, abnormal sex cord organisation and steroid-producing Leydig cell differentiation (Bitgood et al. 1996, Clark et al. 2000, Pierucci-Alves et al. 2001, Yao et al. 2002). Leydig cells express elevated levels of Ptch1 indicating that it is these cells within the testes that are the primary target of Dhh signalling. In the absence of Dhh signalling, the size of the precursor Leydig cell population is unaffected but these cells have reduced expression of the transcription factor steroidogenic factor 1 $(S F-1)$. This is the likely cause of impaired expression of steroidogenic enzymes and ultimately testosterone, which is required for virilisation and spermatogenesis (Yao et al. 2002). While this work has been performed solely in the mouse, in humans disrupted $\mathrm{DHH}$ genes are also correlated with gonadal dysgenesis (Umehara et al. 2000, Canto et al. 2004, 2005). Interestingly, reduced testis size and function observed in offspring exposed to maternal smoking during pregnancy might be linked to significantly decreased $\mathrm{DHH}$ expression in foetal Leydig cells (Fowler et al. 2008).

In the absence of Sry, the gonads develop into ovaries, accompanied by the production of granulosa and subsequently theca cells, which are required for steroidogenesis and gametogenesis (Wilhelm et al. 2007). Dhh null female mice are fertile and viable (Bitgood et al. 1996), suggesting that Hh signalling is not important for female gonad development. However, shortly after birth, granulosa cells in mouse ovaries express both Dhh and Ihh, while Ptch1 and Gli1 mark the differentiating theca cells in the surrounding stroma. Both Dhh and Ihh expression in follicles and Ptch1/ Gli1 expression in surrounding theca cells are lost during ovulation (Wijgerde et al. 2005). A specific role for this signalling in ovarian development or function has not been defined, although Ihh produced by the granulosa cells may complement Dhh function, and thus explain the normal phenotype of Dhh null animals (Wijgerde et al. 2005). Recombinant Shh increased the rate of proliferation of murine granulosa cells in culture and their progesterone production was increased by cyclopamine treatment, indicating that granulosa cells may be a target for Hh signalling (Russell et al. 2007). Epithelial ovarian tumours develop from the surface epithelium, which does not normally express $\mathrm{Hh}$ signalling pathway ligands or target genes. However, $\mathrm{SHH}$ and $\mathrm{DHH}$ are frequently upregulated in ovarian neoplasias. The level of expression of these genes, as well as PTCH1, GLI1 and SMO, correlates well with the aggressiveness of the tumour, with $D H H$ expression levels providing the best prognosis. Cell lines derived from these tumours were growth inhibited by blockading $\mathrm{Hh}$ signalling, indicating that $\mathrm{Hh}$ pathway activation is likely to be critical for their growth (Chen et al. 2007).

\section{The adrenal cortex}

The adrenal cortex and the gonads share a common primordium and this cell population, derived from the mesonephric mesenchyme and overlying coelomic epithelium of the urogenital ridge (see above), is referred to as the 'adrenogenital primordium' (AGP) (Hatano et al. 1996). At around $10 \mathrm{dpc}$ in the mouse, these cells begin to express the transcription factor $S F-1$, which is essential for both adrenal and gonadal development (Luo et al. 1994). At $11 \mathrm{dpc}$, the anterior end of the AGP splits into the bipotential gonad and the adrenocortical primordium, which is located between the gonad and the dorsal aorta. These cells are then invaded by a group of migrating sympathetic neural crest cells that ultimately form the adrenal medulla (Hatano et al. 1996), and the entire cortical plus medullary unit becomes encapsulated by mesenchymal cells. The majority of factors known to affect adrenal development also affect gonadal development and are thus required for the formation of the AGP. These include the transcription factors SF-1, Wilms tumor 1 (WT-1) and Dax-1 (Luo et al. 1994, Muscatelli et al. 1994, Zanaria et al. 1994, Morohashi 1997). Surprisingly, little is known about the signals that specifically control adrenal primordium specification and development or the subsequent zonation of the cortex, but some data implicate a role for the Hh pathway. In situ hybridisation experiments showed Shh mRNA expression restricted to subcapsular adrenocortical cells after segregation of the adrenal and gonadal anlagen in mice (Bitgood \& McMahon 1995). In humans, holoprosencephaly frequently presents with adrenal hypoplasia and hypoadrenalism was noted in the original description of PHS (Hall et al. 1980), 
which is caused by a protein-truncating mutation in GLI3 (Hall et al. 1980). The introduction of a similar Gli3 mutation into mice results in adrenal agenesis at late gestation (Bose et al. 2002). In addition, SLOS is also associated with adrenal insufficiency (Andersson et al. 1999, Chemaitilly et al. 2003).

These observations are all consistent with a requirement for Shh in early adrenal development. However, as described above, defective Shh signalling also causes pituitary agenesis and thus can lead to the loss of POMC-derived pituitary hormones that are required for the trophic support of adrenal growth in post-natal animals. While the adrenal insufficiency observed in these cases might thus be secondary to defective pituitary function, adrenal glands develop normally in POMC null mice (Karpac et al. 2006) indicating that pituitary function is likely to be dispensable for prenatal adrenal development. Our unpublished experiments also indicate that adrenal glands form in $S h h$ null mice but their development is already defective by $12.5 \mathrm{dpc}$, when pituitary POMC expression begins (Liu et al. 2001). Taken as a whole, these data indicate the likelihood of a direct role for Shh in controlling adrenal development. Thus, it is possible that disruption of the Shh signalling pathway is a cause of unassigned cases of adrenal hypoplasia.

\section{Osteogenesis and adipogenesis}

During embryonic development, endochondral bone formation is initiated by the condensation of clusters of mesenchymal cells that differentiate into chondrocytes to form the cartilage anlagen. This is followed by chondrocyte proliferation to expand the cartilage and the subsequent differentiation, growth arrest and hypertrophy of the more medial chondrocytes. Osteoblasts are recruited from the perichondrium and promote ossification at the medial extent of the growth plate. The rates of chondrocyte proliferation and hypertrophy govern the elongation rate of the bone and are processes under complex control, including systemic hormonal signals from the $\mathrm{GH}-$ insulin-like growth factor system, glucocorticoids, thyroid hormone and sex hormones and local signals that include Ihh- and parathyroid-related peptide (PTHrP) (for reviews, see van der Eerden et al. 2003, Kronenberg 2003). Ihh is expressed in prehypertrophic chondrocytes (Bitgood \& McMahon 1995), whereas Ptch1, the Gli genes and Smo are expressed in the distal proliferating chondrocytes as well as in the perichondrium, marking these as the signal receiving cells. Ihh signals directly to less mature chondrocytes where it promotes their proliferation (Long et al. 2001) indirectly to these cells by inducing PTHrP expression in distal periarticular chondrocytes near the ends of the growing bone. PTHrP signalling then acts to delay the differentiation of the proliferating chondrocytes. Ihh and $\mathrm{PTHrP}$ together establish a negative feedback circuit as cartilage growth increases the distance between the distal periarticular $\mathrm{PTHr} P$-expressing cells and the more medial proliferating chondrocytes, which leads to the latter cells differentiating to a pre-hypertrophic state and upregulating
Ihh expression (Karaplis et al. 1994, Lanske et al. 1996, Vortkamp et al. 1996, St Jacques et al. 1999). In addition to controlling chondrocyte proliferation and hypertrophy, Ihh is also required independently of PTHrP for proper formation of the perichondrium, and hence osteoblast formation, and for vascularisation of the bone (Colnot et al. 2005). The crucial roles Ihh plays in chondrocyte proliferation and osteogenesis are dramatically demonstrated in $\mathrm{Ih} h$ null mice, which have markedly malformed long bones that are one-third normal size at birth (St Jacques et al. 1999).

Mesenchymal stem cells are pluripotent cells that can differentiate into osteoblasts, osteoclasts, chondrocytes, adipocytes and other cell types (Tocci \& Forte 2003). The control of these alternative differentiation pathways is crucial for both bone and fat formation and recent data suggest that Hh signalling plays an important role in these processes. Shh, in concert with BMPs, can promote osteoblastic differentiation of the murine mesenchymal C3H10T1/2 (Zehentner et al. 2000, Spinella-Jaegle et al. 2001) and KS483 (van der Horst et al. 2003) cell lines, as well as primary calvaria cell cultures (Spinella-Jaegle et al. 2001). They also block adipogenesis in C3H10T1/2 cells, primary calvaria cells (Spinella-Jaegle et al. 2001), the model adipogenesis cell line 3T3-L1 (Suh et al. 2006) and human mesenchymal stem cells (Fontaine et al. 2008). Furthermore, a Shh transgene blocks fat body formation in Drosophila (Suh et al. 2006). Taken together, these studies provide support for a model in which $\mathrm{Hh}$ provides a pro-bone and anti-fat signal. Further evidence comes from mouse obesity models in which $\mathrm{Hh}$ signal components are reduced in the fat deposits (Suh et al. 2006). BBS patients can present with increased truncal obesity (Tobin \& Beales 2007), and recent data indicate that mice with an inactivating mutation in Ptch1, and hence activated $\mathrm{Hh}$ signalling, have significantly less white adipose tissue than wild-type litter mates (Li et al. 2008). However, some data show a positive relationship between $\mathrm{Hh}$ signalling and adipogenesis. For example, toxicology studies showed that an Shh fusion protein increased fat mass in a reversible fashion (Martin et al. 2002), while signal blocking anti-Shh antibodies can protect mice from diet-induced weight gain (Buhman et al. 2004).

It should be noted, however, that Shh signalling has effects at several levels of metabolic control which may confound efforts to see specific effects on adipogenesis in vivo. Nevertheless, there is an inverse relationship between osteogenesis and adipogenesis in several mesenchymal stem cell models that are controlled, at least in vitro, by $\mathrm{Hh}$ signalling. This suggests a possible role for this signalling pathway in human conditions of imbalance between osteogenesis and adipogenesis, such as the increase in marrow adipose tissue and decrease in bone seen in osteoporosis (Meunier et al. 1971, Verma et al. 2002, Nuttall \& Gimble 2004). Furthermore, Hh pathway activation in human mesenchymal stem cells undergoing adipogenesis leads to insulin resistance, suggesting a potential role for Hh signalling in this pathology (Fontaine et al. 2008). 


\section{Summary}

We have described the current understanding of $\mathrm{Hh}$ signalling and highlighted its role in several endocrine settings. $\mathrm{Hh}$ signalling is required for the development of all the endocrine organs derived from the foregut, as well as the development of the hypothalamo-pituitary-gonadal and hypothalamo-pituitary-adrenal axes, and other organs not discussed here. Defective Hh signalling during embryogenesis is the underlying cause of many endocrine malformation syndromes, and Hh signalling is important in the aetiology of several adult endocrine disorders. These include diabetes, with effects on adiposity, islet $\beta$-cell function and potentially insulin resistance, and osteoporosis, as a consequence of its effect on bone formation. The identification of $\mathrm{Hh}$ signalling in an increasing number of adult stem cells suggests the potential for therapeutic interventions in some or all of these processes in the future. In summary, the $\mathrm{Hh}$ pathway is a fascinating signalling mechanism controlling many fundamental cell processes that are likely to become increasingly studied in the search for the causes of common endocrine disorders and may be explored as a novel avenue for clinical management.

\section{Declaration of Interest}

The authors declare that there is no conflict of interest that could be perceived as prejudicing the impartiality of the research reported.

\section{Funding}

This research did not receive any specific grant from any funding agency in the public, commercial or not-for-profit sector.

\section{References}

Ahn S \& Joyner AL 2004 Dynamic changes in the response of cells to positive hedgehog signaling during mouse limb patterning. Cell 118 505-516.

Andersson HC, Frentz J, Martinez JE, Tuck-Muller CM \& Bellizaire J 1999 Adrenal insufficiency in Smith-Lemli-Opitz syndrome. American Journal of Medical Genetics 82 382-384.

Apelqvist A, Ahlgren U \& Edlund H 1997 Sonic hedgehog directs specialised mesoderm differentiation in the intestine and pancreas. Current Biology 7 801-804.

Ashe HL \& Briscoe J 2006 The interpretation of morphogen gradients. Development 133 385-394.

Athar M, Tang X, Lee JL, Kopelovich L \& Kim AL 2006 Hedgehog signalling in skin development and cancer. Experimental Dermatology 15 667-677.

Bai CB, Auerbach W, Lee JS, Stephen D \& Joyner AL 2002 Gli2, but not Gli1, is required for initial Shh signaling and ectopic activation of the Shh pathway. Development 129 4753-4761.

Bai CB, Stephen D \& Joyner AL 2004 All mouse ventral spinal cord patterning by hedgehog is Gli dependent and involves an activator function of Gli3. Developmental Cell 6 103-115.

Bak M, Hansen C, Friis HK \& Tommerup N 2001 The human hedgehoginteracting protein gene: structure and chromosome mapping to $4 \mathrm{q} 31.21 \rightarrow \mathrm{q} 31.3$. Cytogenetics and Cell Genetics 92 300-303.

Berman DM, Karhadkar SS, Maitra A, Montes DO, Gerstenblith MR, Briggs K, Parker AR, Shimada Y, Eshleman JR, Watkins DN et al. 2003 Widespread requirement for Hedgehog ligand stimulation in growth of digestive tract tumours. Nature 425 846-851.
Berman DM, Desai N, Wang X, Karhadkar SS, Reynon M, Abate-Shen C, Beachy PA \& Shen MM 2004 Roles for Hedgehog signaling in androgen production and prostate ductal morphogenesis. Developmental Biology 267 387-398.

Bhardwaj G, Murdoch B, Wu D, Baker DP, Williams KP, Chadwick K, Ling LE, Karanu FN \& Bhatia M 2001 Sonic hedgehog induces the proliferation of primitive human hematopoietic cells via BMP regulation. Nature Immunology 2 172-180.

Bijlsma MF, Spek CA, Zivkovic D, van de WS, Rezaee F \& Peppelenbosch MP 2006 Repression of smoothened by patched-dependent (pro-)vitamin D3 secretion. PLoS Biology 4 e232.

Bitgood MJ \& McMahon AP 1995 Hedgehog and Bmp genes are coexpressed at many diverse sites of cell-cell interaction in the mouse embryo. Developmental Biology 172 126-138.

Bitgood MJ, Shen L \& McMahon AP 1996 Sertoli cell signaling by desert hedgehog regulates the male germline. Current Biology 6 298-304.

Bose J, Grotewold L \& Ruther U 2002 Pallister-Hall syndrome phenotype in mice mutant for Gli3. Human Molecular Genetics 11 1129-1135.

Buhman KK, Wang LC, Tang Y, Swietlicki EA, Kennedy S, Xie Y, Liu ZY, Burkly LC, Levin MS, Rubin DC et al. 2004 Inhibition of Hedgehog signaling protects adult mice from diet-induced weight gain. Journal of Nutrition 134 2979-2984.

Bumcrot DA, Takada R \& McMahon AP 1995 Proteolytic processing yields two secreted forms of sonic hedgehog. Molecular and Cellular Biology 15 2294-2303.

Burke R, Nellen D, Bellotto M, Hafen E, Senti KA, Dickson BJ \& Basler K 1999 Dispatched, a novel sterol-sensing domain protein dedicated to the release of cholesterol-modified hedgehog from signaling cells. Cell 99 803-815.

Canto P, Soderlund D, Reyes E \& Mendez JP 2004 Mutations in the desert hedgehog $(\mathrm{DHH})$ gene in patients with 46,XY complete pure gonadal dysgenesis. Journal of Clinical Endocrinology and Metabolism 89 4480-4483.

Canto P, Vilchis F, Soderlund D, Reyes E \& Mendez JP 2005 A heterozygous mutation in the desert hedgehog gene in patients with mixed gonadal dysgenesis. Molecular Human Reproduction 11 833-836.

Carstea ED, Morris JA, Coleman KG, Loftus SK, Zhang D, Cummings C, Gu J, Rosenfeld MA, Pavan WJ, Krizman DB et al. 1997 Niemann-Pick C1 disease gene: homology to mediators of cholesterol homeostasis. Science $277228-231$.

Caspary T, Larkins CE \& Anderson KV 2007 The graded response to Sonic Hedgehog depends on cilia architecture. Developmental Cell 12 767-778.

Chamoun Z, Mann RK, Nellen D, von Kessler DP, Bellotto M, Beachy PA \& Basler K 2001 Skinny hedgehog, an acyltransferase required for palmitoylation and activity of the hedgehog signal. Science 293 2080-2084.

Charron F, Stein E, Jeong J, McMahon AP \& Tessier-Lavigne M 2003 The morphogen sonic hedgehog is an axonal chemoattractant that collaborates with Netrin-1 in midline axon guidance. Cell 113 11-23.

Chemaitilly W, Goldenberg A, Baujat G, Thibaud E, Cormier-Daire V \& Abadie V 2003 Adrenal insufficiency and abnormal genitalia in a 46XX female with Smith-Lemli-Opitz syndrome. Hormone Research 59 254-256.

Chen MH, Li YJ, Kawakami T, Xu SM \& Chuang PT 2004 Palmitoylation is required for the production of a soluble multimeric Hedgehog protein complex and long-range signaling in vertebrates. Genes and Development 18 641-659.

Chen MH, Gao N, Kawakami T \& Chuang PT 2005 Mice deficient in the fused homolog do not exhibit phenotypes indicative of perturbed hedgehog signaling during embryonic development. Molecular and Cellular Biology $257042-7053$.

Chen X, Horiuchi A, Kikuchi N, Osada R, Yoshida J, Shiozawa T \& Konishi I 2007 Hedgehog signal pathway is activated in ovarian carcinomas, correlating with cell proliferation: it's inhibition leads to growth suppression and apoptosis. Cancer Science 98 68-76.

Chiang C, Litingtung Y, Lee E, Young KE, Corden JL, Westphal H \& Beachy PA 1996 Cyclopia and defective axial patterning in mice lacking Sonic hedgehog gene function. Nature 383 407-413.

Chuang PT \& McMahon AP 1999 Vertebrate Hedgehog signalling modulated by induction of a Hedgehog-binding protein. Nature 397 617-621. 
Clark AM, Garland KK \& Russell LD 2000 Desert hedgehog (Dhh) gene is required in the mouse testis for formation of adult-type Leydig cells and normal development of peritubular cells and seminiferous tubules. Biology of Reproduction 63 1825-1838.

Colnot C, de la FL, Huang S, Hu D, Lu C, St Jacques B \& Helms JA 2005 Indian hedgehog synchronizes skeletal angiogenesis and perichondrial maturation with cartilage development. Development 132 1057-1067.

Corbit KC, Aanstad P, Singla V, Norman AR, Stainier DY \& Reiter JF 2005 Vertebrate Smoothened functions at the primary cilium. Nature 437 1018-1021.

Corcoran RB \& Scott MP 2006 Oxysterols stimulate Sonic hedgehog signal transduction and proliferation of medulloblastoma cells. PNAS 103 8408-8413.

Cunha GR, Donjacour AA, Cooke PS, Mee S, Bigsby RM, Higgins SJ \& Sugimura Y 1987 The endocrinology and developmental biology of the prostate. Endocrine Reviews 8 338-362.

Dahmane N, Sanchez P, Gitton Y, Palma V, Sun T, Beyna M, Weiner H \& Altaba A 2001 The Sonic Hedgehog-Gli pathway regulates dorsal brain growth and tumorigenesis. Development 128 5201-5212.

D'Amour KA, Bang AG, Eliazer S, Kelly OG, Agulnick AD, Smart NG, Moorman MA, Kroon E, Carpenter MK \& Baetge EE 2006 Production of pancreatic hormone-expressing endocrine cells from human embryonic stem cells. Nature Biotechnology 24 1392-1401.

Dasen JS \& Rosenfeld MG 1999 Signaling mechanisms in pituitary morphogenesis and cell fate determination. Current Opinion in Cell Biology $11669-677$.

Davis EE, Brueckner M \& Katsanis N 2006 The emerging complexity of the vertebrate cilium: new functional roles for an ancient organelle. Developmental Cell 11 9-19.

Docherty K 2001 Growth and development of the islets of Langerhans: implications for the treatment of diabetes mellitus. Current Opinion in Pharmacology 1 641-650.

Doles J, Cook C, Shi X, Valosky J, Lipinski R \& Bushman W 2006 Functional compensation in Hedgehog signaling during mouse prostate development. Developmental Biology 295 13-25.

Dwyer JR, Sever N, Carlson M, Nelson SF, Beachy PA \& Parhami F 2007 Oxysterols are novel activators of the hedgehog signaling pathway in pluripotent mesenchymal cells. Journal of Biological Chemistry 282 8959-8968.

van der Eerden BC, Karperien M \& Wit JM 2003 Systemic and local regulation of the growth plate. Endocrine Reviews 24 782-801.

Eggenschwiler JT \& Anderson KV 2007 Cilia and developmental signaling. Annual Review of Cell and Developmental Biology 23 345-373.

Feldmann G, Dhara S, Fendrich V, Bedja D, Beaty R, Mullendore M, Karikari C, Alvarez H, Iacobuzio-Donahue C, Jimeno A et al. 2007 Blockade of hedgehog signaling inhibits pancreatic cancer invasion and metastases: a new paradigm for combination therapy in solid cancers. Cancer Research 67 2187-2196.

Fontaine C, Cousin W, Plaisant M, Dani C \& Peraldi P 2008 Hedgehog signaling alters adipocyte maturation of human mesenchymal stem cells. Stem Cells 26 1037-1046.

Fowler PA, Cassie S, Rhind SM, Brewer MJ, Collinson JM, Lea RG, Baker PJ, Bhattacharya S \& O'Shaughnessy PJ 2008 Maternal smoking during pregnancy specifically reduces human fetal desert hedgehog gene expression during testis development. Journal of Clinical Endocrinology and Metabolism 93 619-626.

Freestone SH, Marker P, Grace OC, Tomlinson DC, Cunha GR, Harnden P \& Thomson AA 2003 Sonic hedgehog regulates prostatic growth and epithelial differentiation. Developmental Biology 264 352-362.

Gailani MR \& Bale AE 1997 Developmental genes and cancer: role of patched in basal cell carcinoma of the skin. Journal of the National Cancer Institute 89 1103-1109.

Goetz JA, Singh S, Suber LM, Kull FJ \& Robbins DJ 2006 A highly conserved amino-terminal region of sonic hedgehog is required for the formation of its freely diffusible multimeric form. Journal of Biological Chemistry 281 4087-4093.

Gorlin RJ 1995 Nevoid basal cell carcinoma syndrome. Dermatologic Clinics 13 113-125.

Guerrero I \& Chiang C 2007 A conserved mechanism of Hedgehog gradient formation by lipid modifications. Trends in Cell Biology 17 1-5.
Hahn H, Wicking C, Zaphiropoulous PG, Gailani MR, Shanley S, Chidambaram A, Vorechovsky I, Holmberg E, Unden AB, Gillies S et al. 1996 Mutations of the human homolog of Drosophila patched in the nevoid basal cell carcinoma syndrome. Cell 85 841-851.

Hall JG, Pallister PD, Clarren SK, Beckwith JB, Wiglesworth FW, Fraser FC, Cho S, Benke PJ \& Reed SD 1980 Congenital hypothalamic hamartoblastoma, hypopituitarism, imperforate anus and postaxial polydactyly - a new syndrome? Part I: clinical, causal, and pathogenetic considerations American Journal of Medical Genetics 7 47-74.

Hatano O, Takakusu A, Nomura M \& Morohashi K 1996 Identical origin of adrenal cortex and gonad revealed by expression profiles of Ad4BP/SF-1. Genes to Cells 1 663-671.

Haycraft CJ, Banizs B, Aydin-Son Y, Zhang Q, Michaud EJ \& Yoder BK 2005 Gli2 and Gli3 localize to cilia and require the intraflagellar transport protein polaris for processing and function. PLoS Genetics 1 e53.

Hebrok M, Kim SK \& Melton DA 1998 Notochord repression of endodermal Sonic hedgehog permits pancreas development. Genes and Development 12 1705-1713

Hebrok M, Kim SK, St Jacques B, McMahon AP \& Melton DA 2000 Regulation of pancreas development by hedgehog signaling. Development 127 4905-4913.

Hill P, Wang B \& Ruther U 2007 The molecular basis of Pallister Hall associated polydactyly. Human Molecular Genetics 16 2089-2096.

van der Horst G, Farih-Sips H, Lowik CW \& Karperien M 2003 Hedgehog stimulates only osteoblastic differentiation of undifferentiated KS483 cells. Bone 33 899-910.

Huangfu D \& Anderson KV 2005 Cilia and Hedgehog responsiveness in the mouse. PNAS 102 11325-11330.

Huangfu D \& Anderson KV 2006 Signaling from Smo to Ci/Gli: conservation and divergence of Hedgehog pathways from Drosophila to vertebrates. Development 133 3-14.

Huangfu D, Liu A, Rakeman AS, Murcia NS, Niswander L \& Anderson KV 2003 Hedgehog signalling in the mouse requires intraflagellar transport proteins. Nature 426 83-87.

Ingham PW \& McMahon AP 2001 Hedgehog signaling in animal development: paradigms and principles. Genes and Development 15 3059-3087.

Johnson RL, Rothman AL, Xie J, Goodrich LV, Bare JW, Bonifas JM, Quinn AG, Myers RM, Cox DR \& Epstein EH Jr 1996 Human homolog of patched, a candidate gene for the basal cell nevus syndrome. Science 272 1668-1671.

Jonsson J, Carlsson L, Edlund T \& Edlund H 1994 Insulin-promoter-factor 1 is required for pancreas development in mice. Nature 371 606-609.

Karaplis AC, Luz A, Glowacki J, Bronson RT, Tybulewicz VL, Kronenberg HM \& Mulligan RC 1994 Lethal skeletal dysplasia from targeted disruption of the parathyroid hormone-related peptide gene. Genes and Development 8 277-289.

Karhadkar SS, Bova GS, Abdallah N, Dhara S, Gardner D, Maitra A, Isaacs JT, Berman DM \& Beachy PA 2004 Hedgehog signalling in prostate regeneration, neoplasia and metastasis. Nature 431 707-712.

Karpac J, Ostwald D, Li GY, Bui S, Hunnewell P, Brennan MB \& Hochgeschwender U 2006 Proopiomelanocortin heterozygous and homozygous null mutant mice develop pituitary adenomas. Cellular and Molecular Biology 52 47-52.

Kawahira H, Ma NH, Tzanakakis ES, McMahon AP, Chuang PT \& Hebrok M 2003 Combined activities of hedgehog signaling inhibitors regulate pancreas development. Development 130 4871-4879.

Kayed H, Kleeff J, Keleg S, Buchler MW \& Friess H 2003 Distribution of Indian hedgehog and its receptors patched and smoothened in human chronic pancreatitis. Journal of Endocrinology 178 467-478.

Kayed H, KleeffJ, Keleg S, Guo J, Ketterer K, Berberat PO, Giese N, Esposito I, Giese T, Buchler MW et al. 2004 Indian hedgehog signaling pathway: expression and regulation in pancreatic cancer. International Journal of Cancer $110668-676$.

Keeler RF \& Binns W 1968 Teratogenic compounds of Veratrum californicum (Durand). V. Comparison of cyclopian effects of steroidal alkaloids from the plant and structurally related compounds from other sources. Teratology 15-10.

Kelley RI \& Hennekam RC 2000 The Smith-Lemli-Opitz syndrome. Journal of Medical Genetics 37 321-335. 
Kiefer JC 2003 Molecular mechanisms of early gut organogenesis: a primer on development of the digestive tract. Developmental Dynamics 228 287-291.

Kim SK \& Melton DA 1998 Pancreas development is promoted by cyclopamine, a hedgehog signaling inhibitor. PNAS 95 13036-13041.

Kimura S, Hara Y, Pineau T, Fernandez-Salguero P, Fox CH, Ward JM \& Gonzalez FJ 1996 The T/ebp null mouse: thyroid-specific enhancerbinding protein is essential for the organogenesis of the thyroid, lung, ventral forebrain, and pituitary. Genes and Development 10 60-69.

Kogerman P, Grimm T, Kogerman L, Krause D, Unden AB, Sandstedt B, Toftgard R \& Zaphiropoulos PG 1999 Mammalian suppressor-of-fused modulates nuclear-cytoplasmic shuttling of Gli-1. Nature Cell Biology 1312-319.

Kronenberg HM 2003 Developmental regulation of the growth plate. Nature 423 332-336.

Kuwabara PE \& Labouesse M 2002 The sterol-sensing domain: multiple families, a unique role? Trends in Genetics 18 193-201.

Lai K, Kaspar BK, Gage FH \& Schaffer DV 2003 Sonic hedgehog regulates adult neural progenitor proliferation in vitro and in vivo. Nature Neuroscience 6 21-27.

Lam CW, Xie J, To KF, Ng HK, Lee KC, Yuen NW, Lim PL, Chan LY, Tong SF \& McCormick F 1999 A frequent activated smoothened mutation in sporadic basal cell carcinomas. Oncogene 18 833-836.

Lanske B, Karaplis AC, Lee K, Luz A, Vortkamp A, Pirro A, Karperien M, Defize LH, Ho C, Mulligan RC et al. 1996 PTH/PTHrP, receptor in early development and Indian hedgehog-regulated bone growth. Science 273 663-666.

Lee JJ, Ekker SC, von Kessler DP, Porter JA, Sun BI \& Beachy PA 1994 Autoproteolysis in hedgehog protein biogenesis. Science 266 1528-1537.

Li Z, Zhang H, Denhard LA, Liu LH, Zhou H \& Lan ZJ 2008 Reduced white fat mass in adult mice bearing a truncated Patched 1. International Journal of Biological Sciences 4 29-36.

Liu J, Lin C, Gleiberman A, Ohgi KA, Herman T, Huang HP, Tsai MJ \& Rosenfeld MG 2001 Tbx19, a tissue-selective regulator of POMC gene expression. PNAS 98 8674-8679.

Liu A, Wang B \& Niswander LA 2005 Mouse intraflagellar transport proteins regulate both the activator and repressor functions of Gli transcription factors. Development 132 3103-3111.

Loftus SK, Morris JA, Carstea ED, Gu JZ, Cummings C, Brown A, Ellison J, Ohno K, Rosenfeld MA, Tagle DA et al. 1997 Murine model of Niemann-Pick C disease: mutation in a cholesterol homeostasis gene. Science 277 232-235.

Long F, Zhang XM, Karp S, Yang Y \& McMahon AP 2001 Genetic manipulation of hedgehog signaling in the endochondral skeleton reveals a direct role in the regulation of chondrocyte proliferation. Development 128 5099-5108.

Luo X, Ikeda Y \& Parker KL 1994 A cell-specific nuclear receptor is essential for adrenal and gonadal development and sexual differentiation. Cell 77 481-490.

Machold R, Hayashi S, Rutlin M, Muzumdar MD, Nery S, Corbin JG, GritliLinde A, Dellovade T, Porter JA, Rubin LL et al. 2003 Sonic hedgehog is required for progenitor cell maintenance in telencephalic stem cell niches. Neuron 39 937-950.

Manning L, Ohyama K, Saeger B, Hatano O, Wilson SA, Logan M \& Placzek M 2006 Regional morphogenesis in the hypothalamus: a BMP-Tbx2 pathway coordinates fate and proliferation through Shh downregulation. Developmental Cell 11 873-885.

Marigo V, Johnson RL, Vortkamp A \& Tabin CJ 1996 Sonic hedgehog differentially regulates expression of GLI and GLI3 during limb development. Developmental Biology 180 273-283.

Martin PL, Lane J, Pouliot L, Gains M, Stejskal R, Smith SY, Galdes A \& Green J 2002 Increases in adipose and total body weight, but not in lean body mass, associated with subcutaneous administration of Sonic hedgehog-Ig fusion protein to mice. Drug Development Research 57 107-114.

Martinelli DC \& Fan CM 2007a Gas1 extends the range of Hedgehog action by facilitating its signaling. Genes \& Development 21 1231-1243.

Martinelli DC \& Fan CM $2007 b$ The role of Gas1 in embryonic development and its implications for human disease. Cell Cycle 6.

Mathieu J, Barth A, Rosa FM, Wilson SW \& Peyrieras N 2002 Distinct and cooperative roles for Nodal and Hedgehog signals during hypothalamic development. Development 129 3055-3065.

May SR, Ashique AM, Karlen M, Wang B, Shen Y, Zarbalis K, Reiter J, Ericson J \& Peterson AS 2005 Loss of the retrograde motor for IFT disrupts localization of Smo to cilia and prevents the expression of both activator and repressor functions of Gli. Developmental Biology 287 378-389.
Merchant M, Evangelista M, Luoh SM, Frantz GD, Chalasani S, Carano RA, van Hoy M, Ramirez J, Ogasawara AK, McFarland LM et al. 2005 Loss of the serine/threonine kinase fused results in postnatal growth defects and lethality due to progressive hydrocephalus. Molecular and Cellular Biology 25 7054-7068.

Meunier P, Aaron J, Edouard C \& Vignon G 1971 Osteoporosis and the replacement of cell populations of the marrow by adipose tissue. A quantitative study of 84 iliac bone biopsies. Clinical Orthopaedics and Related Research 80 147-154.

Ming JE, Kaupas ME, Roessler E, Brunner HG, Golabi M, Tekin M, Stratton RF, Sujansky E, Bale SJ \& Muenke M 2002 Mutations in PATCHED-1, the receptor for SONIC HEDGEHOG, are associated with holoprosencephaly. Human Genetics 110 297-301.

Morohashi K 1997 The ontogenesis of the steroidogenic tissues. Genes to Cells 2 95-106.

Murtaugh LC 2007 Pancreas and beta-cell development: from the actual to the possible. Development 134 427-438.

Muscatelli F, Strom TM, Walker AP, Zanaria E, Recan D, Meindl A, Bardoni B, Guioli S, Zehetner G, Rabl W et al. 1994 Mutations in the DAX-1 gene give rise to both $\mathrm{X}$-linked adrenal hypoplasia congenita and hypogonadotropic hypogonadism. Nature 372 672-676.

Nanni L, Ming JE, Bocian M, Steinhaus K, Bianchi DW, Die-Smulders C, Giannotti A, Imaizumi K, Jones KL, Campo MD et al. 1999 The mutational spectrum of the sonic hedgehog gene in holoprosencephaly: SHH mutations cause a significant proportion of autosomal dominant holoprosencephaly. Human Molecular Genetics 8 2479-2488.

Nusslein-Volhard C \& Wieschaus E 1980 Mutations affecting segment number and polarity in Drosophila. Nature 287 795-801.

Nuttall ME \& Gimble JM 2004 Controlling the balance between osteoblastogenesis and adipogenesis and the consequent therapeutic implications. Current Opinion in Pharmacology 4 290-294.

Odent S, Atti-Bitach T, Blayau M, Mathieu M, Aug J, Delezo DA, Gall JY, Le Marec B, Munnich A, David V et al. 1999 Expression of the Sonic hedgehog (SHH) gene during early human development and phenotypic expression of new mutations causing holoprosencephaly. Human Molecular Genetics 8 1683-1689.

Offield MF, Jetton TL, Labosky PA, Ray M, Stein RW, Magnuson MA, Hogan BL \& Wright CV 1996 PDX-1 is required for pancreatic outgrowth and differentiation of the rostral duodenum. Development 122 983-995.

Outram SV, Varas A, Pepicelli CV \& Crompton T 2000 Hedgehog signaling regulates differentiation from double-negative to double-positive thymocyte. Immunity 13 187-197.

Pabst O, Herbrand H, Takuma N \& Arnold HH 2000 NKX2 gene expression in neuroectoderm but not in mesendodermally derived structures depends on sonic hedgehog in mouse embryos. Development Genes and Evolution 210 47-50.

Palma V, Lim DA, Dahmane N, Sanchez P, Brionne TC, Herzberg CD, Gitton Y, Carleton A, Alvarez-Buylla A \& Altaba A 2005 Sonic hedgehog controls stem cell behavior in the postnatal and adult brain. Development 132 335-344.

Parkin CA \& Ingham PW 2008 The adventures of Sonic Hedgehog in development and repair. I. Hedgehog signaling in gastrointestinal development and disease. American Journal of Physiology. Gastrointestinal and Liver Physiology 294 G363-G367.

Peacock CD, Wang Q, Gesell GS, Corcoran-Schwartz IM, Jones E, Kim J, Devereux WL, Rhodes JT, Huff CA, Beachy PA et al. 2007 Hedgehog signaling maintains a tumor stem cell compartment in multiple myeloma. PNAS 104 4048-4053.

Pepinsky RB, Zeng C, Wen D, Rayhorn P, Baker DP, Williams KP, Bixler SA, Ambrose CM, Garber EA, Miatkowski K et al. 1998 Identification of a palmitic acid-modified form of human Sonic hedgehog. Journal of Biological Chemistry 273 14037-14045.

Pierucci-Alves F, Clark AM \& Russell LD 2001 A developmental study of the desert hedgehog-null mouse testis. Biology of Reproduction 65 1392-1402.

Podlasek CA, Barnett DH, Clemens JQ, Bak PM \& Bushman W 1999 Prostate development requires Sonic hedgehog expressed by the urogenital sinus epithelium. Developmental Biology 209 28-39.

Porter JA, Young KE \& Beachy PA 1996 Cholesterol modification of hedgehog signaling proteins in animal development. Science 274 255-259. 
Prado CL, Pugh-Bernard AE, Elghazi L, Sosa-Pineda B \& Sussel L 2004 Ghrelin cells replace insulin-producing beta cells in two mouse models of pancreas development. PNAS 101 2924-2929.

Ramalho-Santos M, Melton DA \& McMahon AP 2000 Hedgehog signals regulate multiple aspects of gastrointestinal development. Development 127 2763-2772.

Reifenberger J, Wolter M, Knobbe CB, Kohler B, Schonicke A, Scharwachter C, Kumar K, Blaschke B, Ruzicka T \& Reifenberger G 2005 Somatic mutations in the PTCH, SMOH, SUFUH and TP53 genes in sporadic basal cell carcinomas. British Journal of Dermatology 152 43-51.

Roessler E, Du YZ, Mullor JL, Casas E, Allen WP, Gillessen-Kaesbach G, Roeder ER, Ming JE, Altaba A \& Muenke M 2003 Loss-of-function mutations in the human GLI2 gene are associated with pituitary anomalies and holoprosencephaly-like features. PNAS 100 13424-13429.

Rohatgi R, Milenkovic L \& Scott MP 2007 Patched1 regulates hedgehog signaling at the primary cilium. Science 317 372-376.

Russell MC, Cowan RG, Harman RM, Walker AL \& Quirk SM 2007 The hedgehog signaling pathway in the mouse ovary. Biology of Reproduction $\mathbf{7 7}$ 226-236.

Sanchez P, Hernandez AM, Stecca B, Kahler AJ, DeGueme AM, Barrett A, Beyna M, Datta MW, Datta S \& Altaba A 2004 Inhibition of prostate cancer proliferation by interference with SONIC HEDGEHOG-GLI1 signaling. PNAS 101 12561-12566.

Scully KM \& Rosenfeld MG 2002 Pituitary development: regulatory codes in mammalian organogenesis. Science 295 2231-2235.

Shannon JM \& Hyatt BA 2004 Epithelial-mesenchymal interactions in the developing lung. Annual Review of Physiology 66 625-645.

Sheng T, Chi S, Zhang X \& Xie J 2006 Regulation of Gli1 localization by the cAMP/protein kinase A signaling axis through a site near the nuclear localization signal. Journal of Biological Chemistry 281 9-12.

Slack JM 1995 Developmental biology of the pancreas. Development 121 $1569-1580$

Spence JR \& Wells JM 2007 Translational embryology: using embryonic principles to generate pancreatic endocrine cells from embryonic stem cells. Developmental Dynamics 236 3218-3227.

Spinella-Jaegle S, Rawadi G, Kawai S, Gallea S, Faucheu C, Mollat P, Courtois B, Bergaud B, Ramez V, Blanchet AM et al. 2001 Sonic hedgehog increases the commitment of pluripotent mesenchymal cells into the osteoblastic lineage and abolishes adipocytic differentiation. Journal of Cell Science 114 2085-2094.

St Jacques B, Hammerschmidt M \& McMahon AP 1999 Indian hedgehog signaling regulates proliferation and differentiation of chondrocytes and is essential for bone formation. Genes and Development 13 2072-2086.

Suh JM, Gao X, McKay J, McKay R, Salo Z \& GraffJM 2006 Hedgehog signaling plays a conserved role in inhibiting fat formation. Cell Metabolism 3 25-34.

Svard J, Heby-Henricson K, Persson-Lek M, Rozell B, Lauth M, Bergstrom A, Ericson J, Toftgard R \& Teglund S 2006 Genetic elimination of Suppressor of fused reveals an essential repressor function in the mammalian Hedgehog signaling pathway. Developmental Cell 10 187-197.

Tempe D, Casas M, Karaz S, Blanchet-Tournier MF \& Concordet JP 2006 Multisite protein kinase A and glycogen synthase kinase $3 \beta$ phosphorylation leads to Gli3 ubiquitination by SCF $\beta \operatorname{TrCP}$. Molecular and Cellular Biology 26 4316-4326.

Thayer SP, di Magliano MP, Heiser PW, Nielsen CM, Roberts DJ, Lauwers GY, Q1 YP, Gysin S, Fernandez-del Castillo C, Yajnik Vet al. 2003 Hedgehog is an early and late mediator of pancreatic cancer tumorigenesis. Nature 425 851-856.

Thomas MK, Rastalsky N, Lee JH \& Habener JF 2000 Hedgehog signaling regulation of insulin production by pancreatic beta-cells. Diabetes 49 2039-2047.

Thomas MK, Lee JH, Rastalsky N \& Habener JF 2001 Hedgehog signaling regulation of homeodomain protein islet duodenum homeobox-1 expression in pancreatic $\beta$-cells. Endocrinology 142 1033-1040.

Tobin JL \& Beales PL 2007 Bardet-Biedl syndrome: beyond the cilium. Pediatric Nephrology 22 926-936.

Tocci A \& Forte L 2003 Mesenchymal stem cell: use and perspectives. Hematology Journal 4 92-96.

Treier M, Gleiberman AS, O'Connell SM, Szeto DP, McMahon JA, McMahon AP \& Rosenfeld MG 1998 Multistep signaling requirements for pituitary organogenesis in vivo. Genes and Development 12 1691-1704.
Treier M, O’Connell S, Gleiberman A, Price J, Szeto DP, Burgess R, Chuang PT, McMahon AP \& Rosenfeld MG 2001 Hedgehog signaling is required for pituitary gland development. Development 128 377-386.

Trowbridge JJ, Scott MP \& Bhatia M 2006 Hedgehog modulates cell cycle regulators in stem cells to control hematopoietic regeneration. PNAS $\mathbf{1 0 3}$ 14134-14139.

Umehara F, Tate G, Itoh K, Yamaguchi N, Douchi T, Mitsuya T \& Osame M 2000 A novel mutation of desert hedgehog in a patient with 46,XY partial gonadal dysgenesis accompanied by minifascicular neuropathy. American Journal of Human Genetics 67 1302-1305.

Verma S, Rajaratnam JH, Denton J, Hoyland JA \& Byers RJ 2002 Adipocytic proportion of bone marrow is inversely related to bone formation in osteoporosis. Journal of Clinical Pathology 55 693-698.

Vila G, Papazoglou M, Stalla J, Theodoropoulou M, Stalla GK, Holsboer F \& Paez-Pereda M 2005a Sonic hedgehog regulates CRH signal transduction in the adult pituitary. FASEB Journal 19 281-283.

Vila G, Theodoropoulou M, Stalla J, Tonn JC, Losa M, Renner U, Stalla GK \& Paez-Pereda M 2005b Expression and function of sonic hedgehog pathway components in pituitary adenomas: evidence for a direct role in hormone secretion and cell proliferation. Journal of Clinical Endocrinology and Metabolism 90 6687-6694.

Vokes SA, Ji H, McCuine S, Tenzen T, Giles S, Zhong S, Longabaugh WJ, Davidson EH, Wong WH \& McMahon AP 2007 Genomic characterization of Gli-activator targets in sonic hedgehog-mediated neural patterning. Development 134 1977-1989.

Vortkamp A, Lee K, Lanske B, Segre GV, Kronenberg HM \& Tabin CJ 1996 Regulation of rate of cartilage differentiation by Indian hedgehog and PTH-related protein. Science 273 613-622.

Wang B \& Li Y 2006 Evidence for the direct involvement of $\beta \operatorname{TrCP}$ in Gli3 protein processing. PNAS 103 33-38.

Warburton D, Schwarz M, Tefft D, Flores-Delgado G, Anderson KD \& Cardoso WV 2000 The molecular basis of lung morphogenesis. Mechanisms of Development 92 55-81.

Watkins DN \& Peacock CD 2004 Hedgehog signalling in foregut malignancy. Biochemical Pharmacology 68 1055-1060.

Watkins DN, Berman DM, Burkholder SG, Wang B, Beachy PA \& Baylin SB 2003 Hedgehog signalling within airway epithelial progenitors and in smallcell lung cancer. Nature 422 313-317.

Wijgerde M, Ooms M, Hoogerbrugge JW \& Grootegoed JA 2005 Hedgehog signaling in mouse ovary: Indian hedgehog and desert hedgehog from granulosa cells induce target gene expression in developing theca cells. Endocrinology 146 3558-3566.

Wilhelm D, Palmer S \& Koopman P 2007 Sex determination and gonadal development in mammals. Physiological Reviews 87 1-28.

Yao HH, Whoriskey W \& Capel B 2002 Desert Hedgehog/Patched 1 signaling specifies fetal Leydig cell fate in testis organogenesis. Genes and Development 16 1433-1440.

Zanaria E, Muscatelli F, Bardoni B, Strom TM, Guioli S, Guo W, Lalli E, Moser C, Walker AP, McCabe ER et al. 1994 An unusual member of the nuclear hormone receptor superfamily responsible for X-linked adrenal hypoplasia congenita. Nature 372 635-641.

Zehentner BK, Leser U \& Burtscher H 2000 BMP-2 and sonic hedgehog have contrary effects on adipocyte-like differentiation of C3H10T1/2 cells. DNA and Cell Biology 19 275-281.

Zhou JX, Jia LW, Liu WM, Miao CL, Liu S, Cao YJ \& Duan EK 2006 Role of sonic hedgehog in maintaining a pool of proliferating stem cells in the human fetal epidermis. Human Reproduction 21 1698-1704.

Zurawel RH, Allen C, Chiappa S, Cato W, Biegel J, Cogen P, de Sauvage F \& Raffel C 2000 Analysis of PTCH/SMO/SHH pathway genes in medulloblastoma. Genes, Chromosomes and Cancer 27 44-51.

Received in final form 30 May 2008

Accepted 4 June 2008

Made available online as an Accepted Preprint 4 June 2008 